\title{
Late Triassic platform, slope and basin deposits in the Pilis Mountains, Transdanubian Range, Hungary
}

\author{
János Haas* \\ Eötvös Loránd University, Budapest
}

Péter Szeitz

Eötvös Loránd University, Budapest

\author{
Tamás Budai, Olga Piros \\ Geological Institute of Hungary, Budapest
}

Ágnes Görög

Eötvös Loránd University, Budapest

In the Pilis Range, NW of Budapest, contemporaneous Upper Triassic platform and basin facies occur. The paper presents the extent and basic characteristics of these facies with interpretation of their depositional conditions, and summarizes the available biostratigraphic data. Based on previous and recent studies a general depositional model is displayed and the history of the basin evolution is outlined. Within the Dachstein Platform an extensional intraplatform basin (Feketehegy Basin) came into existence during the middle part of the Norian. An asymmetric basin was formed, bounded by steep and gentle slopes, respectively. The platform progradation that may have resulted in the termination of the basin began at the gentle margin probably in the latest Norian-earliest Rhaetian.

Key words: Transdanubian Range, Pilis Mts, Late Triassic, facies analysis, platform and basin evolution

\section{Introduction}

Knowledge of the Triassic formations in the Pilis Mountains was based mainly on data obtained from earlier geologic mapping and the study of key sections. There has been remarkable progress as far as the stratigraphy and sedimentology of the basinal formations are concerned; however, our knowledge of the shallowmarine platform carbonates, which comprise the bulk of the Triassic succession, can be qualified as "conventional". Accordingly, the goal of our research supported by the Hungarian Scientific Research Fund (OTKA) - was to extend the detailed stratigraphic and sedimentological analysis to the shallow-marine

\footnotetext{
Addresses: J. Haas, P. Szeitz, Á. Görög: H-1117 Budapest, Pázmány P. stny 1/c, Hungary T. Budai, O. Piros: H-1143 Budapest, Stefánia út 14, Hungary

*Corresponding author; e-mail: haas@ludens.elte.hu

Received: February 2, 2011; accepted: March 22, 2011
} 
Triassic formations of the Pilis Mts, in order to obtain data which may serve as a basis for reconstruction of the evolution and paleogeographic setting of platforms and basins. We attempted to determine the age of platform carbonates on the basis of the dasycladalean flora and foraminiferal fauna, and reconstruct the connection between coeval platforms and basins via analysis of the sedimentary structures and microfacies. For the interpretation of the evolutionary history and paleogeographic setting, experience obtained from the reconstruction of the Late Triassic basin evolution in the Northern and Southern Alps was also taken into consideration.

\section{Geologic setting}

The Norian to Rhaetian succession of the Transdanubian Range shows a characteristic trend of vertical and lateral facies changes. The main part of the range (the Bakony, the Vértes and the Gerecse Mts) is built up by cyclic platform carbonates from the Upper Carnian (Hauptdolomit) to the Rhaetian (Dachstein Limestone), the thickness of which can reach 2,000 m. However, on the southwestern and the northeastern side of the huge platform, carbonates of basinal facies can be traced from the Middle Norian (Rezi Dolomite and Kössen Formations in the Zala Basin and in the Keszthely Mts, Feketehegy Limestone in the Pilis Mts), or even from the Carnian (Mátyáshegy and Csóvár Formations in the Buda Mts and in the Csôvár blocks). The extent of Upper Norian to Rhaetian formations of the Transdanubian Range and their stratigraphic position is shown in Figs 1 and 2.

The Pilis Mts are found in the northeastern part of the Transdanubian Range, close to the bend of the Danube (Fig. 3). The NW-SE elongated range is built up predominantly by the thick platform carbonates of the Hauptdolomit and the Dachstein Limestone Fms, while on the northeastern side of the range the Feketehegy Limestone of basinal facies can be found. The Feketehegy Fm. is not known west of the Pilis Range but according to a limited amount of subsurface data it continues eastward in the basement of the Visegrád Mts. The Pilis is separated both from the Buda Hills and Dorog Basin to the SW, and from the Miocene volcanites of the Visegrád Mts to the NE, by SE to NW-striking tectonic zones.

\section{Previous studies}

The Triassic formations of the Pilis Mts had already been studied already the classical period of Hungarian geology. The first detailed maps of the area were published by Schafarzik (1898, 1902, 1904). Thin-bedded limestone rich in mollusks was already mentioned by Stache (1866) and Koch $(1871 \mathrm{a}, \mathrm{b})$ in the vicinity of Pilisszentlélek. Based on detailed mapping Schafarzik (1884a, b) reported gray, bituminous limestone above the dolomite (Hauptdolomit) containing Avicula lumachelle. Later this formation was correlated with the 
Rhaetian Kössen beds of the Bakony Mountains by Lóczy (1913, 1916). This classification was then adapted by Schafarzik and Vendl (1929), who published the first detailed geologic map of the Pilis - Kétágú Hill range.

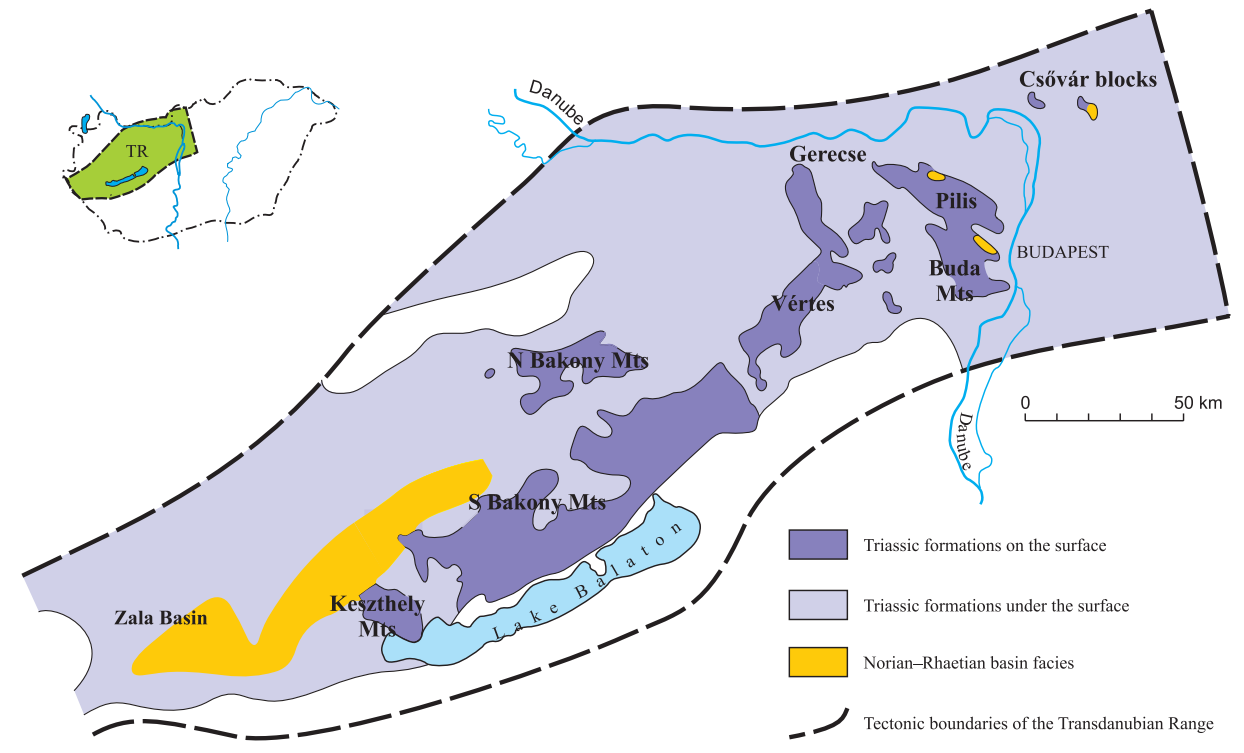

Fig. 1

Extent of Norian to Rhaetian formations of the Transdanubian Range (after Haas 2002)

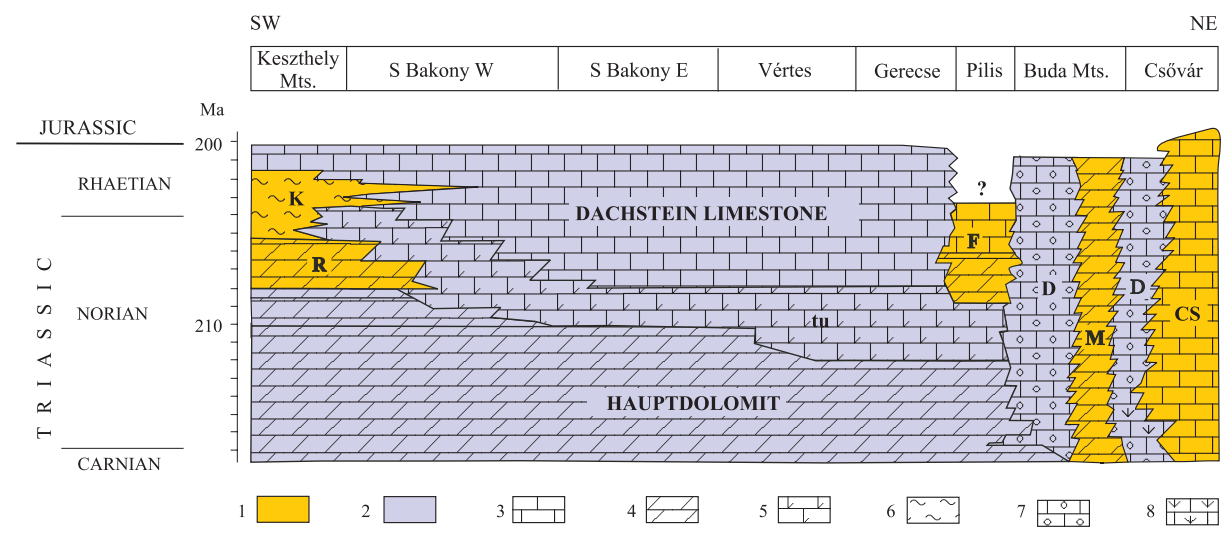

Fig. 2

Stratigraphic classification of Norian to Rhaetian formations of the Transdanubian Range (modified after Haas, 2002). 1. basin facies; 2 . platform facies; 3 . limestone; 4 . dolomite; 5 . dolomite and limestone alternation, 6. marl; 7. oncoidal facies; 8. reef facies. Abbreviations: Cs - Csôvár Limestone; D Dachstein Limestone (oncoidal facies); F - Feketehegy Limestone; K - Kössen Formation; M Mátyáshegy Fm.; R - Rezi Dolomite; tu - transitional unit (Fenyőfő Mb) 


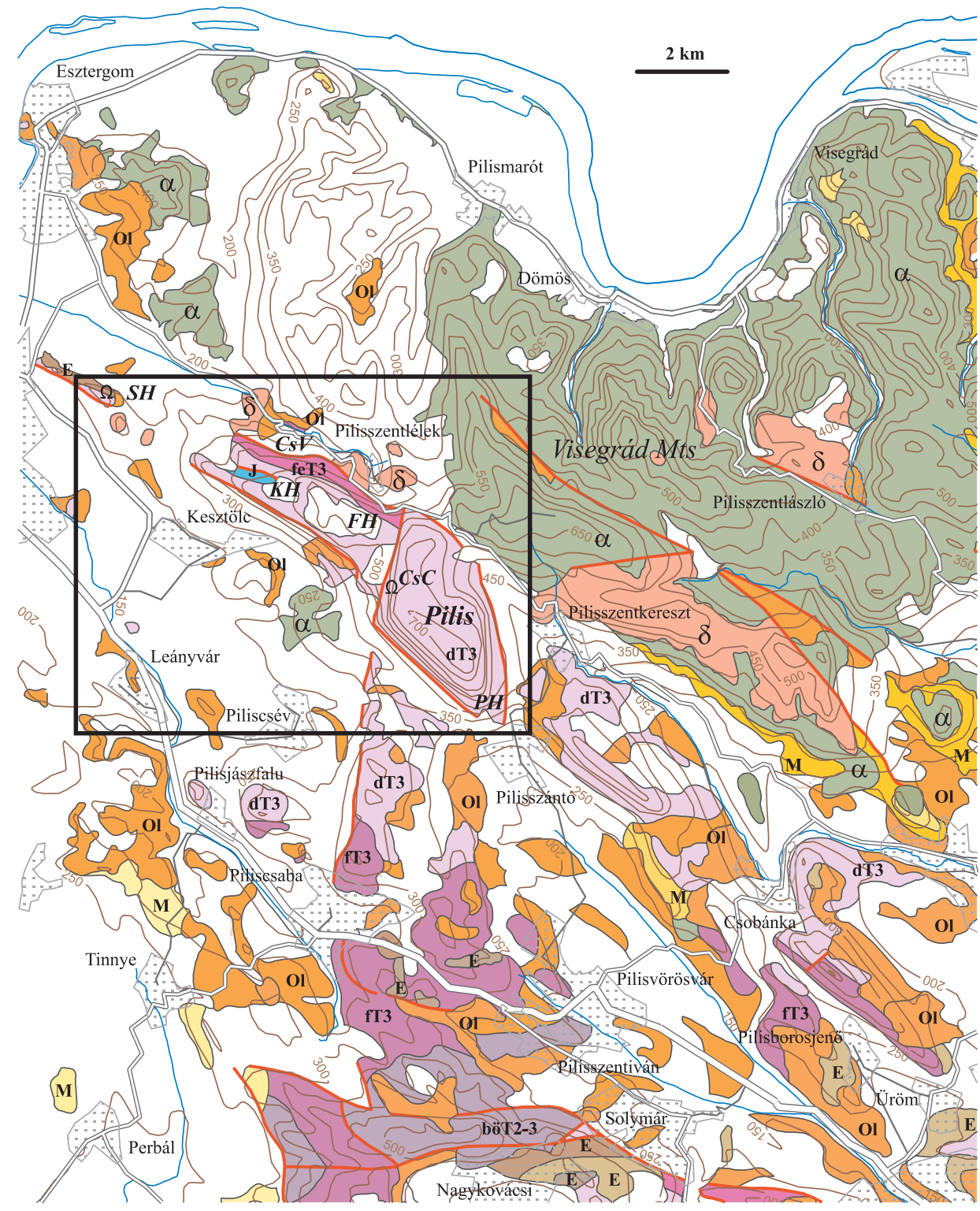

Fig. 3

Geologic map of the Pilis and Visegrád Mts. (simplified after Budai and Gyalog, eds., 2009) showing the study area. Detailed sections: PH - Pilis Hill (see also Fig. 4); CsC - Csév Cliffs (see also Fig. 7); KH - Kétágú Hill (see also Fig. 11); SH - Nagy-Strázsa Hill; FH - Fekete Hill (see also Fig. 18/A); CsV Cserepes Valley (see also Fig. 18/B). Symbols: $\alpha$-Middle Miocene andesite; $\delta$-Middle Miocene dacite; $\mathrm{M}$ - Miocene sediments; Ol - Oligocene formations; E - Eocene formations; J - Jurassic formations; dT3 - Dachstein Limestone; feT3 - Feketehegy Formation; fT3 - Hauptdolomit; böT2-3 - Budaörs Dolomite 
At the beginning of the 60s field studies were carried out in the northwestern part of the Pilis Mts (Reményi 1950). Field work combined with fossil collection was carried out by Oravecz (1961) on Fekete-hegy (Fekete Hill). Emphasizing the absence of Avicula contorta in the so-called "Feketehegy layers" he classified them with the Upper Carnian. Based on Rhabdoceras suessi found in Cserepes Valley he assigned that succession to the Norian.

Balogh (1961) summarized the problems of the Triassic stratigraphy of the Pilis Mts.

In connection with the detailed geologic mapping of the Dorog Basin, the Upper Triassic formations of the Fekete Hill - Kétágú Hill range were studied by Nagy (1964a, b, 1968, 1969). He subdivided the Upper Triassic sequence into the following units (from base to top): brown dolomite, dark grey bituminous laminated limestone with Avicula lumachelle, Hauptdolomit, Halobia-bearing limestone, Dachstein Limestone. He mentioned that stratigraphic connections between these units were unclear because of tectonic disturbances. Based on megalodontids he assigned the lower part of the Dachstein Limestone to the Norian and its upper part (near the Jurassic outcrops) to the Rhaetian in the succession of Velka Skala (Öreg-szirt).

The 200-250 m thick Avicula-bearing, so-called "Feketehegy limestone" was assigned to the Upper Carnian to Lower Norian range by Végh-Neubrandt (1978). Balogh (1981) defined the dolomite and bituminous limestone succession as the Feketehegy Formation and assigned it to the Norian.

Megalodontids from the Dachstein Limestone of the Pilis Mts were reported by several authors (Schafarzik 1884a, b; Vígh 1928; Ferencz 1953; Nagy 1968, 1969, etc.). It was Végh-Neubrandt (1982) who provided a complete list of the fauna collected from several localities: Neomegalodon guembeli guembeli, N. complanatus complanatus, Gemmelarodus amplus amplus, G. seccoi seccoi, Dicerocardium pannonicum, Dicerocardium sp. All of these taxa are Norian; no older or younger forms were mentioned from the Pilis area.

Foraminifera of the Upper Triassic platform and basin facies were comprehensively studied by Oravecz-Scheffer (1987). She recognized a NorianRhaetian assemblage (Schlagerina cf. angustiumbilicata and a Schmidita hedbergelloides) from the Feketehegy Formation. However, it should be mentioned that the determination as Oberhauserellidae (Schlagerina cf. angustiumbilicata and Schmidita hedbergelloides) is not correct, due to their agglutinated walls (1987, pl. XCII, figs 10, 11); the forms in question are probably trochamminids.

Kovács determined a monospecific conodont-assemblage (Metapolygnathus slovakensis) from the Feketehegy Limestone and assigned it into the MiddleUpper Norian (Kovács and Nagy 1989). According to their opinion the Aviculaand Halobia-bearing limestone beds are coeval and both belong to the Feketehegy Formation.

Recently Haas et al. (2005) carried out detailed sedimentological investigations of the stratotype section of the Feketehegy Formation, interpreted the 
depositional conditions, the basin evolution, and set up a paleoenvironmental model for the development of the Feketehegy Basin during the Middle to Late Norian interval.

\section{Studied localities}

To clarify the connection between the Upper Triassic platform and basin facies, representative sections along the Pilis Range were selected and studied in detail (Fig. 3).

\section{Platform carbonate sections}

\section{Pilis Hill}

Pilis Hill is located west of Pilisszántó. It was mapped by Ferencz (1953) in detail. He assigned the main part of Pilis Hill to the Dachstein Limestone, except for the dolomite beds at the southern edge of the hill that were assigned to the Hauptdolomit.

The coffin-shape Pilis Hill is a northwestward tilted block that is made up mostly of Dachstein Limestone. It has a steep southern slope towards Pilisszántó that is subdivided by a valley into two ridges (Fig. 4). Our studies revealed that these ridges have significantly different stratigraphic settings and tectonic structures (these facts were not evident on the earlier geologic maps). A

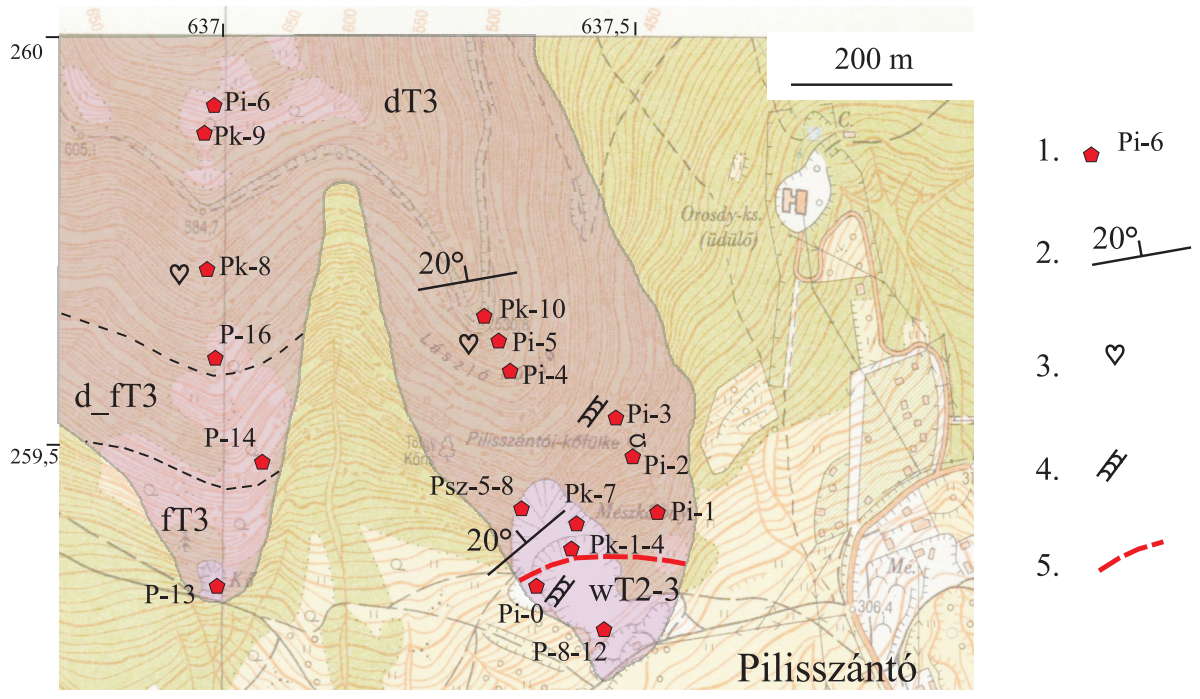

Fig. 4

Surface extension of Triassic platform carbonates in the southern part of Pilis Hill (lilac on the map). 1. Sampling site; 2. dip; 3. megalodontids; 4. green algae; 5 . tectonic contact. Abbreviations: wT2-3"Wetterstein-type" platform limestone; fT3 - Fődolomit (Hauptdolomit) Fm; d_fT3 - Fenyőfő Mb (Dachstein Limestone Fm); dT3 - Dachstein Limestone Fm 
succession of Haupdolomit (exposed in a small quarry at the southern foot of the range), through a transitional interval that is made up of a dolomite-limestone alternation (Fenyőfó Member) up to the typical Dachstein Limestone, can be traced along the western ridge, whereas the eastern ridge is made up exclusively of limestone of platform facies. The rock is heavily fractured on both sides of the valley that separates the two ridges, so there is no doubt that the valley is tectonically controlled.

There is a large limestone quarry (Pilisszántó Quarry) at the southern foot of the eastern ridge, where thick-bedded limestone is exposed in three quarry yards.

In the lower yard thick beds intercalated with a $0.5 \mathrm{~m}$-thick calcrete horizon are visible. Centimeter-sized gastropods and bivalves (among others $\mathrm{cm}$-sized megalodontids) occur in the lowermost exposed bed. The thick beds are characterized by clotted microsparitic texture with tiny peloids and calcimicrobes and 1-10 mm-sized molds of dasycladalean algae (Fig. 5a-c). Bioclastic grainstone with fine and coarse-grained calcarenite is common. The coarse fraction contains fragments of thick-shelled bivalves and gastropods. Dasycladalean-bearing microfacies were also encountered; although due to their poor preservation determination of the fossils was not possible. The strongly recrystallised foraminiferal fauna consists of Glomospirella spp., Trochammina spp., Duostominidae, Aulotortus sp. and Triadodiscus eomesozoicus (Oberhauser 1957). There are no index fossils among them; the range of T. eomesozoicus is Anisian-Norian (Rettori 1995).

Massive to thick-bedded limestone is also exposed in the middle yard. In a sample (Pi-0) taken from the western wall of the middle yard Diplopora annulata (Fig. 5a) and Trochammina almtalensis Koehn-Zaninetti were found in these beds constraining their Middle Triassic age. Based on these biostratigraphic data this sample represents Wetterstein-type platform facies. Limestone exposed in the lower yard show similar lithological features; however, the biostratigraphic constraints are missing.

At the base of the northern wall of the middle yard an approximately $4 \mathrm{~m}$-thick bed of yellowish-gray, $\mathrm{cm}$ to $\mathrm{m}$-sized clasts is visible. Above it $30-50 \mathrm{~cm}$-thick, yellowish gray or darker gray laminitic layers alternate with light gray, 1.0-1.2 mthick beds. The samples taken from the gray beds are characterized by clotted micritic, microsparitic texture with tiny peloids, microbial nodules, lumps (Fig. $5 \mathrm{~d}$ ), and various amounts of bioclasts. Fragments of dasycladalean algae usually occur, as do some gastropods, foraminifera and ostracodes. In the thick beds exposed in the northern wall of the middle yard the foraminiferal fauna consists of strongly recrystallized involutinids [I. cf. communis (Kristan), I. sinuosa (Weynschenk)] as well as some Trochammina sp. and Duostominidae species. This part of the section is rich in dasycladaleans: Physoporella leptotheca KochanskyDevide, Heteroporella zankli (Ott), Griphoporella sp., Acicularia sp. The foraminiferal fauna and the dasycladalean flora indicate Norian age (samples Pk-1-4). The 

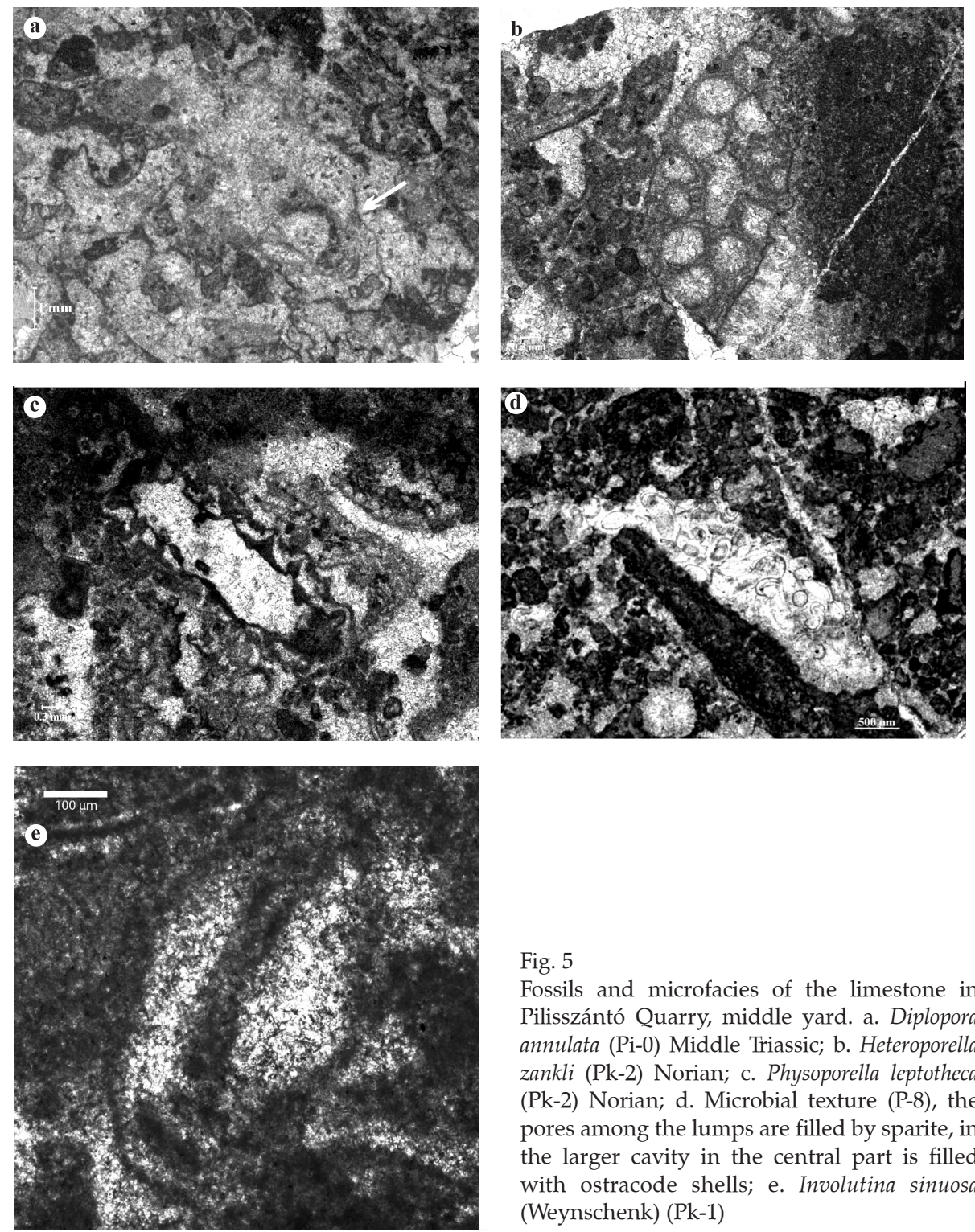

Fig. 5

Fossils and microfacies of the limestone in Pilisszántó Quarry, middle yard. a. Diplopora annulata (Pi-0) Middle Triassic; b. Heteroporella zankli (Pk-2) Norian; c. Physoporella leptotheca (Pk-2) Norian; d. Microbial texture (P-8), the pores among the lumps are filled by sparite, in the larger cavity in the central part is filled with ostracode shells; e. Involutina sinuosa (Weynschenk) (Pk-1)

brownish-gray calcrete bed is characterized by a diagenetic grainstone texture consisting of peloids, lumps and solution pores with sparitic fill between them. Some of the pores are filled with ostracodes in sparitic cement (Fig. 5d).

In the upper yard and on the slope above it, typical Lofer-cyclic Dachstein Limestone is exposed. In this part the dasycladalean flora is poor, with badly- 
preserved Norian specimens (Physoporella leptotheca Kochansky-Devide, Griphoporella sp.). The foraminiferal fauna (Involutina cf. communis (Kristan), Involutina sinuosa (Weynschenk) (Fig. 5/e), Aulotortus friedli (Kristan-Tollmann) (Pk-7) indicate the (Upper-)Norian age of that succession (Gazdzicki 1983; Senowbari-Daryan et al. 2010).

Tectonic contact must be supposed between the Middle Triassic and the Upper Triassic platform carbonate formations (Fig. 4), and the contact between the massive and thick-bedded Norian limestone and the Lofer-cyclic one is probably also a tectonic one.

Several samples were taken from the outcrops east of the quarry (Fig. 4), near the Pilisszántó caves (Pi-1-3). This limestone shows similar microfacies characteristics with the rocks of the upper quarry yard. Peloidal, bioclastic and locally oolitic grainstone (Pi-3c) is most typical. Molds of fragments of thickshelled bivalves, gastropods, foraminifera (Agathammina austroalpina KristanTollmann and Tollmann) (Fig. 6/c) are usually present and fragments of


Fig. 6

Microfossils and outcrop of Dachstein Limestone, Pilisszántó. a. Griphoporella curvata Gümbel (Norian), Pilisszántó caves, Pi-3; b. Subtidal and peritidal members of a Lofer cycle, cliff at the edge of the Pilis plateau; c. Agathammina austroalpina (Kristan-Tollmann and Tollmann) (Pi-3 sample) 
dasycladalean algae (Griphoporella curvata Gümbel) also occur in some samples (Fig. 6a). A network of solution pores filled by ostracodal micrite internal sediment and sparite cement was encountered in sample Pi-4. Several Agathammina austroalpina, Glomospira sp., and Trochammina sp. occur in sample Pi-4, but in sample Pi-3/A A. austroalpina is frequent. In sample Pi-5 Aulotortus friedli and Involutina sinuosa are the characteristic foraminiferal species, together with some Trochammina sp.

The Dachstein Limestone that crops out on the slope above the quarry, and also on the plateau near the top of Pilis Hill (Pi-4-5 and Pk-10) is made up of Lofer-cycles (Fig. 6b). Northwestward tilting of the block of Pilis Hill is reflected in the general $20^{\circ} \mathrm{NW}$ dip of these beds. The thick-bedded bioclastic subtidal facies are often rich in megalodontids. The stromatolite beds may reach $0.5-0.8 \mathrm{~m}$ in thickness. Samples taken from the subtidal facies are typified by peloidal, bioclastic packstone or grainstone with a few mollusk shell fragments, fragments of echinoderms, ostracodes, and relicts of foraminifera.

\section{Csév Cliffs (Csévi-szirtek)}

The Csév Cliffs ( $\mathrm{CsC}$ in Fig. 3) expose the Dachstein Limestone in the middle part of the western side of Pilis Hill (Fig. 7), E of Klastrompuszta (Kesztölc). The succession is definitely Lofer-cyclic. A characteristic outcrop section (CsSz-6) of $358 / 40^{\circ}$ dipping, measured at the northwestern part of the cliff, $\mathrm{N}$ of Leány Cave, is presented in Fig. 8.
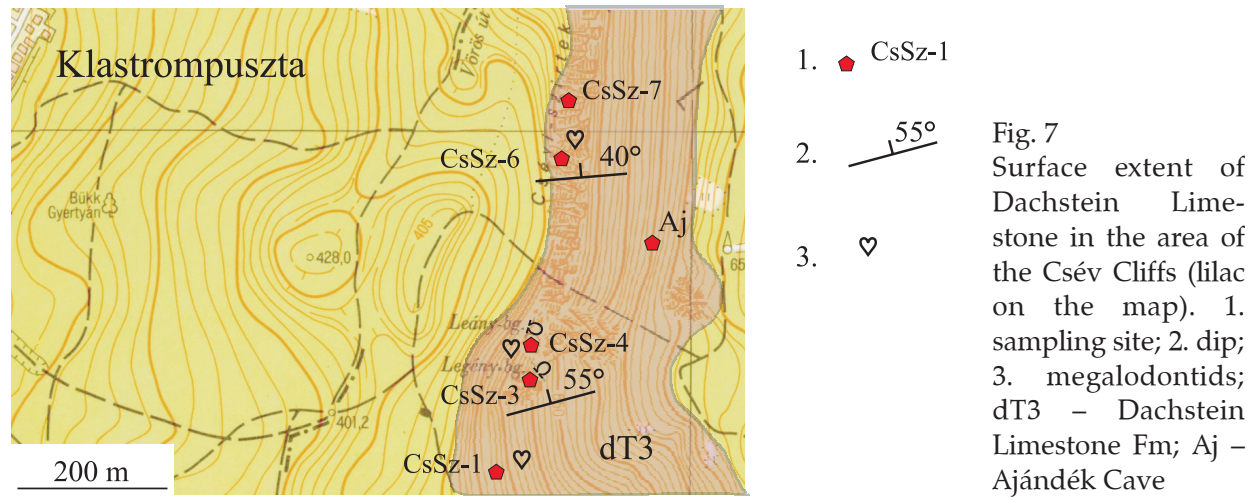

In the upper part of a meter-thick bed of subtidal facies (member C) a $40 \mathrm{~cm}$ thick interval typified by sheet-cracks was found in the basal part of the section. Above an uneven disconformity surface (d) it is overlain by a $30 \mathrm{~cm}$-thick argillaceous limestone layer of yellowish, pinkish color, with $\mathrm{mm}$-cm-sized intraclasts and fenestral pores (member A) (Fig. 9a). Molds of ostracodes were found in the matrix. It is followed by a stromatolite bed (member B) and then an 


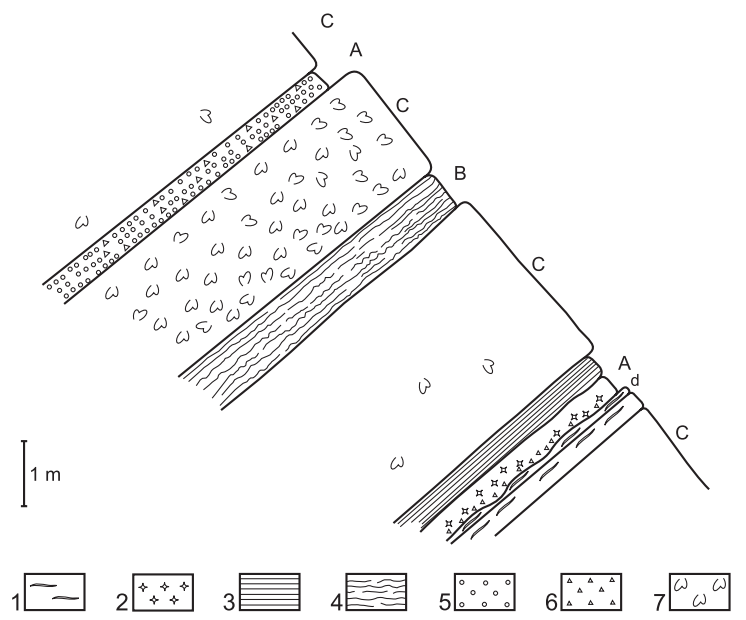

Fig. 8

Measured section of the Dachstein Limestone, north of Leány Cave (CsSz-6). 1. sheet-cracks; 2. fenestral pores; 3. laminated bedding; 4 stromatolite; 5 . coated grains; 6 . lithoclasts; 7. megalodontids; $\mathrm{d}$. disconformity surface
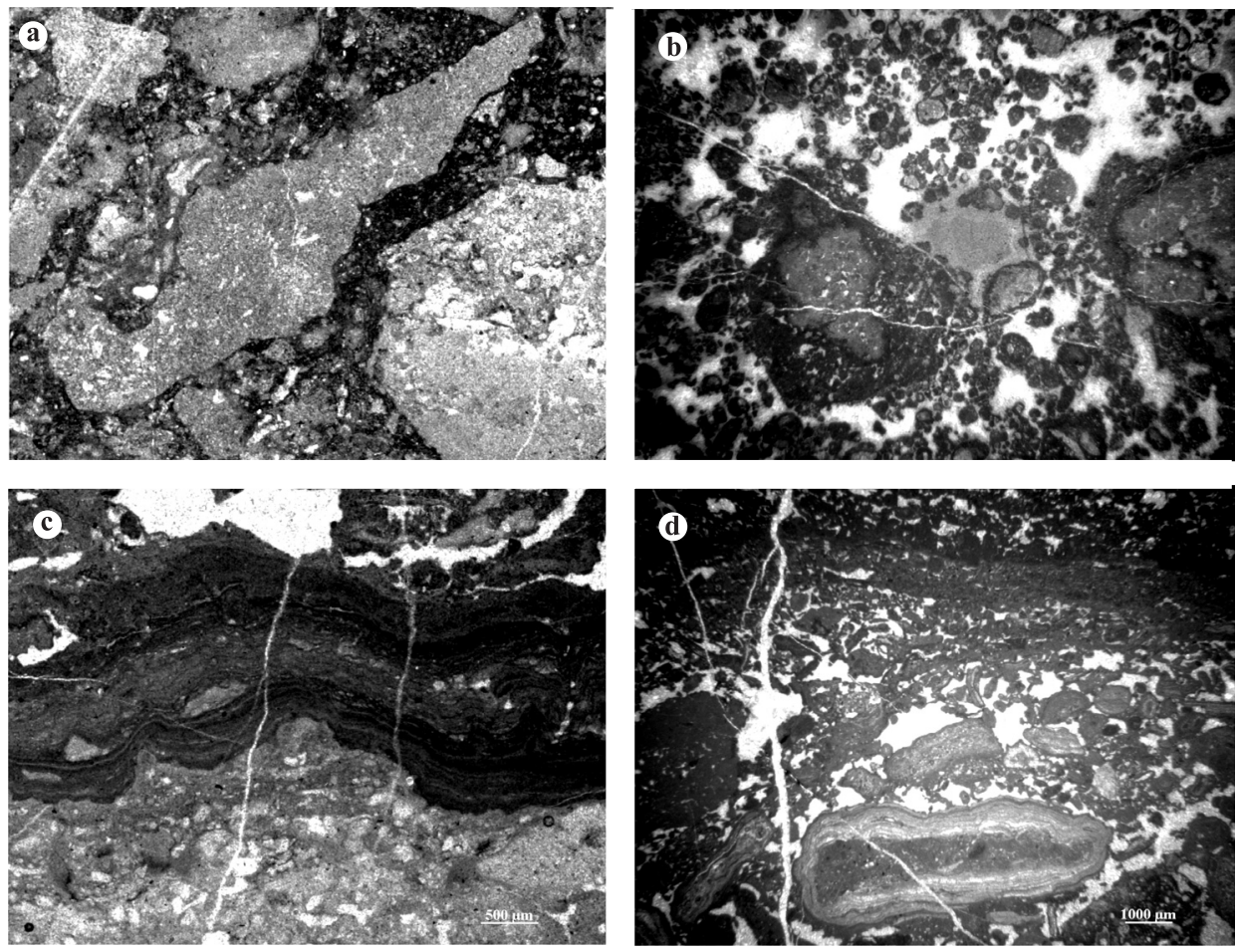

Fig. 9

Microfacies of the Dachstein Limestone at Csév Cliffs. a. intraclasts and fenestral pores (member A), Csév Cliffs, CsSz-6, 4. sample; b. microbial nodules enveloped by microbial crusts, Csév Cliffs, CsSz6, 9. sample; c. laminar calcrete, Ajándék Cave, (Aj6a1_h sample); d. vadose pisoids, Ajándék Cave (Aj6a2_d sample) 
approximately $3 \mathrm{~m}$-thick subtidal bed with a few scattered megalodont fragments, that grades upward to stromatolite without any definite disconformity surface. Next is a subtidal bed (member C), very rich in megalodontids (Fig. 10). It is overlain by a $40 \mathrm{~cm}$-thick yellow limestone layer of rather special microfabric. The rock is made up of microbial peloids and mmsized microbial nodules, in some cases enveloped by multiple microbial crusts (Fig. 9b). These particles are usually surrounded by thin calcite cement, showing features of the pendant cement, locally implying vadose, meteoric, early diagenetic conditions. The remnant pores are filled with crystal silt and/or drusy calcite. This bed may have been formed in the peritidal zone and was subsequently subject to subaerial exposure.

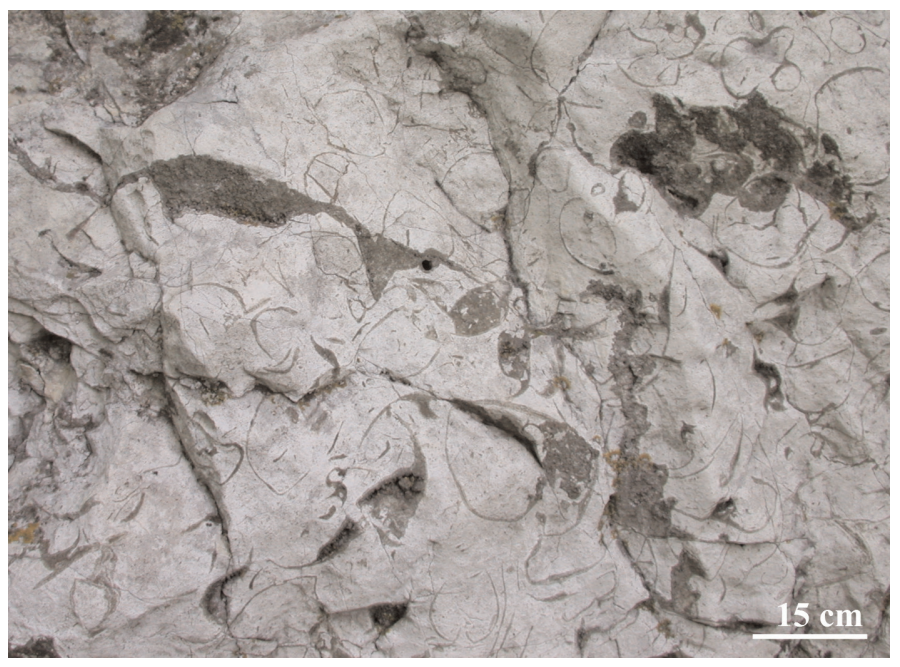

Fig. 10

Megalodont shells in Lofer-cycle member C. Csév Cliffs, CsSz-6

Similar Lofer-cyclic Dachstein Limestone occurs in the southeastern part of Csév Cliffs from Vacska Cave to Legény Cave. Some laminated peritidal interbeds between the megalodont-bearing subtidal beds are of particular interest. Northwest of Vacska Cave a $0.5 \mathrm{~m}$-thick laminated calcrete bed was encountered. It is made up of various clasts, $0.5-5 \mathrm{~mm}$ in size, in a micritic matrix and with fenestral pores of similar size. Along with the most typical peloidal wackestone clasts that may contain tiny fenestrae, brown limonitic clasts (probably weathering crust fragments) also occur. Some of the larger fenestral pores may have been root casts enlarged by solution.

Further northwestward a $25 \mathrm{~cm}$-thick stromatolite bed was studied. It shows many characteristic features of the laminated microbial fabric. Some of the lamina have clotted peloidal structure with tiny micrite-walled spherical objects; the others are characterized by larger and locally amalgamated fenestrae formed by desiccation and subsequent solution, and filled with sparry calcite. 
Spectacular Lofer-cyclic beds were encountered in Ajándék Cave. In the exposed interval, megalodont-bearing beds (peloidal, bioclastic wackestone and grainstone) alternate with dm-thick, well-developed laminar calcretes (Fig. 9c), which are mostly made up of mm-sized vadose pisoids and lumps (Fig. 9d). Shrinkage pores and cracks and larger cavities filled by ostracodal micrite below and isopachous sparry calcite above, occur. In some samples the relics of the original texture could also be recognized; stromatolites may have been subject to pedogenic alteration.

\section{Kétágú Hill (Kétágú-hegy)}

The Kétágú Hill range strikes SSE-NNW along the tectonically-controlled western margin of the Pilis Mts (Fig. 3). It is built up by a cyclic succession of the Dachstein Limestone dipping $20^{\circ}-25^{\circ} \mathrm{NNE}$. Along this range three sections were studied (Fig. 11): Öreg Cliff (Öreg-szirt), Fehér Cliff (Fehér-szirt) and Kesztölc Quarry (Ke-I).

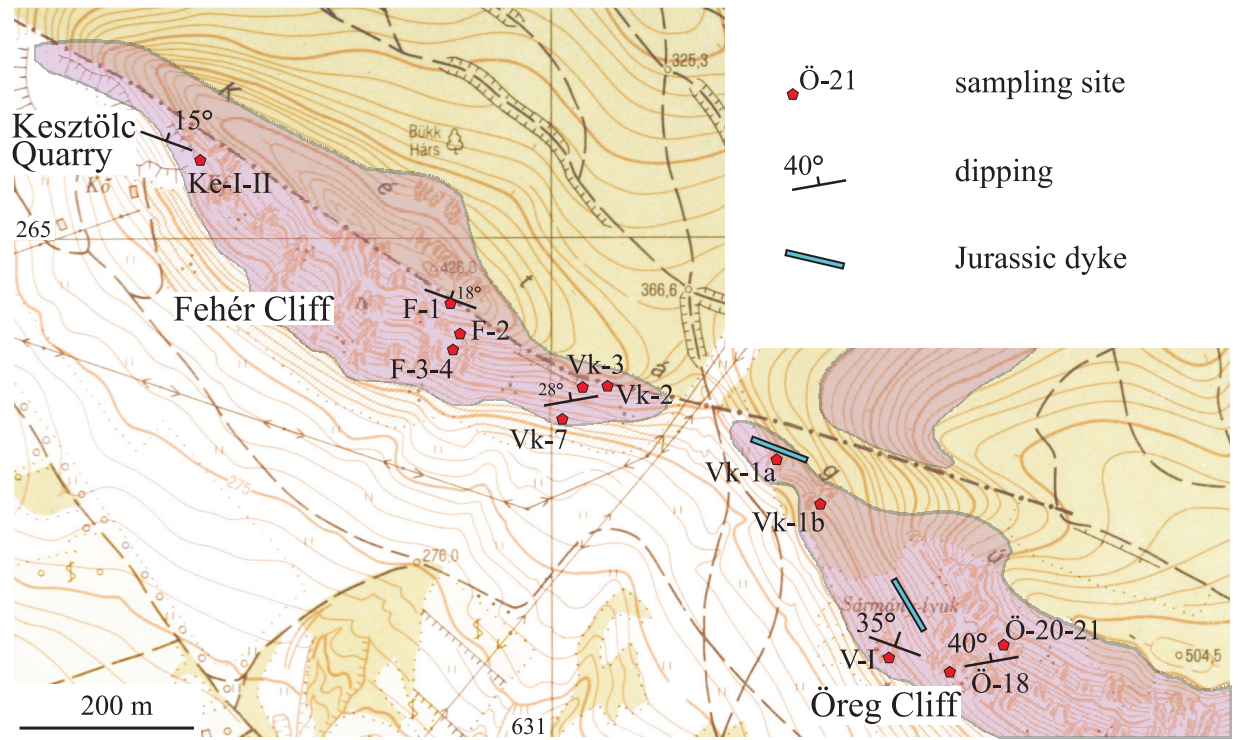

Fig. 11

Surface extent of Dachstein Limestone (lilac on the map) along Kétágú Hill, showing the locations of the sampling sites and of the measured sections (V-I, Ke-I)

The bedded Dachstein Limestone is almost continuously exposed along the tectonically-controlled southwestern slope of Kétágú Hill. However, due to the NW-SE trending telescopic fault system and perpendicular faults, only segments of the succession could be measured within the small fault-controlled structural blocks. Although fitting of the segments could not be performed, the measured and sampled sections provided information on the typical facies and the 
characteristics of the cyclic facies changes. Taking into account the general $\mathrm{N}$ to NE-ward dipping of the beds, the southeastern part of the rocky slope could expose the older elements of the Dachstein Limestone. Accordingly the section of Öreg Cliff will be presented first, followed by a discussion of the outcrop and quarry exposures of Fehér Cliff.

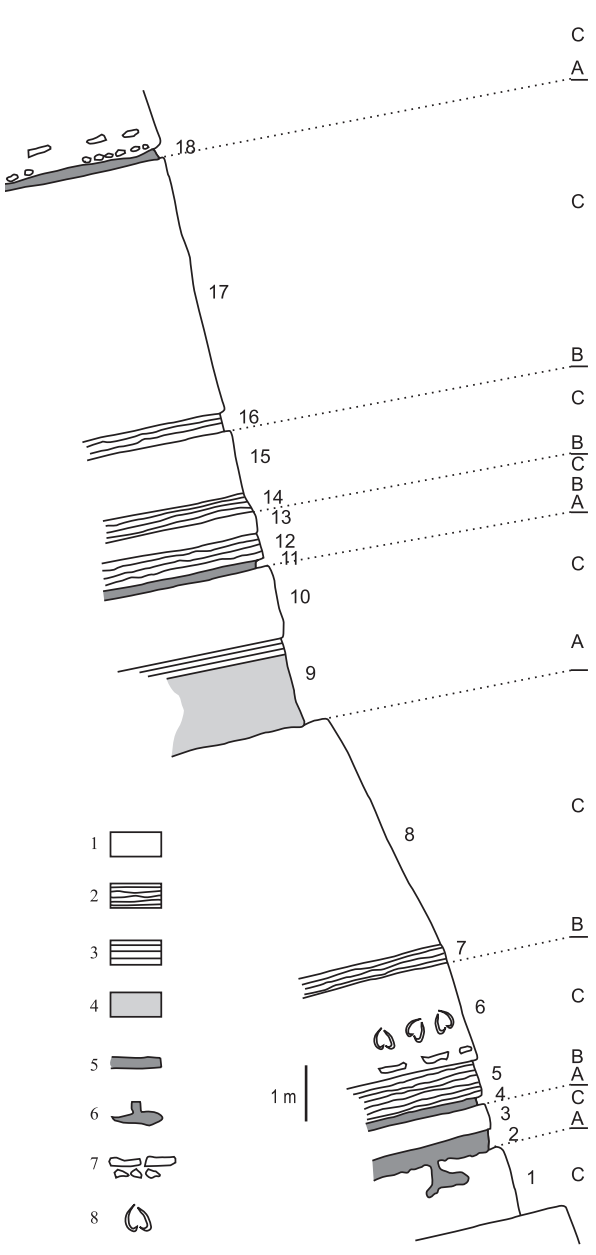

Fig. 12

Measured section V-I in Fig. 11 of the Dachstein Limestone in the lower part of Öreg Cliff (1-18: sampled layers). 1. subtidal facies of C-member; 2. stromatolite of B-member; 3. laminite; 4. yellowish-pinkish limestone (member A); 5. brownish-red paleosol layer of member A; 6. karstic cavities filled with brownish-red paleosol; 7. rip-up stromatolite breccia; 8. megalodonts
At the lower part of Öreg Cliff an approximately $20 \mathrm{~m}$-thick, continuous cyclic succession (V-I in Fig. 11) could be studied (Fig. 12). The cycles are usually bounded by uneven disconformity surfaces. Karstic solution pockets filled by pale red limestone from the overlying bed were observed on the top of bed 1. Red or yellowishpink limestone (member A) or yellowish, drab stromatolites (member B) appear above the disconformity surfaces; however, in some cases facies $\mathrm{A}$ is followed by facies $\mathrm{B}$. The thickness of facies A is usually 10 to $40 \mathrm{~cm}$, but in bed 9 it is $1.5 \mathrm{~m}$. The thickness of facies $B$ is $20-40 \mathrm{~cm}$. The facies A or B is followed by the light grey facies $C$. It is characterized by peloidal or bioclastic, peloidal wackestone-packstone, and bioclastic wackestone texture. In situ embedded megalodontids were found in bed 6. The thickness of members $C$ of the cycles is very variable ( 0.3 to 4.6 $\mathrm{m})$.

The conditions of exposure of the higher part of Öreg Cliff did not allow the measuring of continuous successions. Only a few samples were taken from here (Fig. 11). Peletal, bioclastic wackestone with Favreina pellets were found in sample Ö-20; bioclastic wackestone with $1-10 \mathrm{~mm}$ sized intraclasts were encountered in sample Ö-18 (Fig. 13a) and Ö-21.

In sample O-18 great number of Aulotortus friedli (Fig. 13/e), some involutinids (Involutina sp. and Aulo- 
conus permodiscoides [Oberhauser]), Glomospira sp., Glomospirella sp. were found, which suggest the Late Norian age of this bed (Gazdzicki 1983).

Further to the NW, along the valley separating Öreg Cliff and Fehér Cliff, a $120^{\circ}-300^{\circ}$ striking neptunian dyke, $60 \mathrm{~cm}$ wide and filled with pink crinoidal

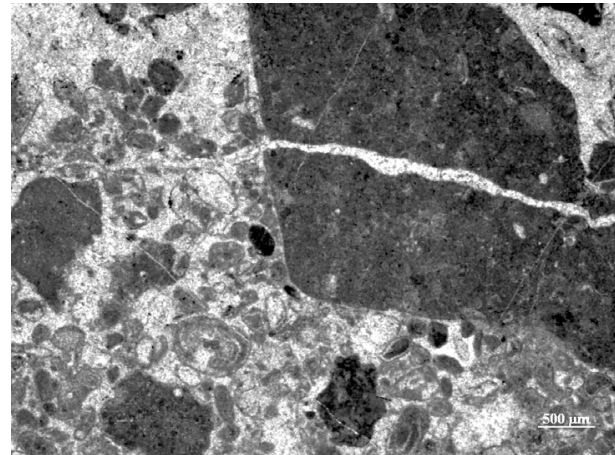

a

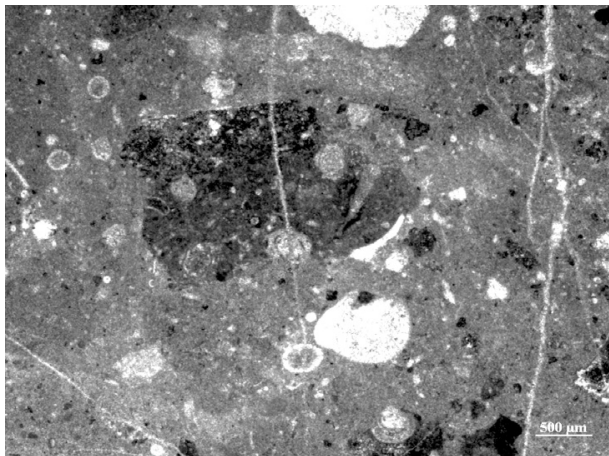

c

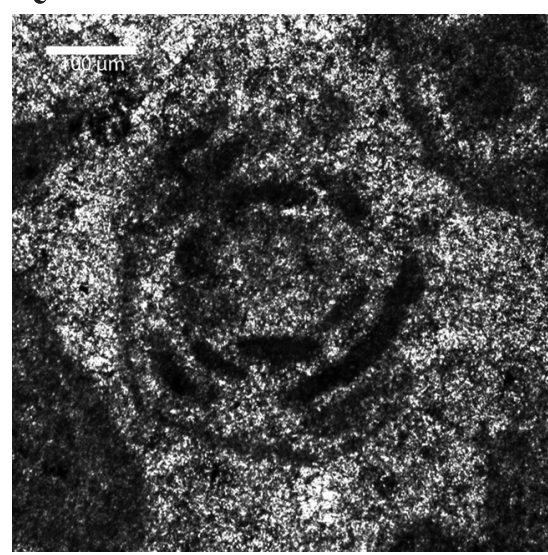

e

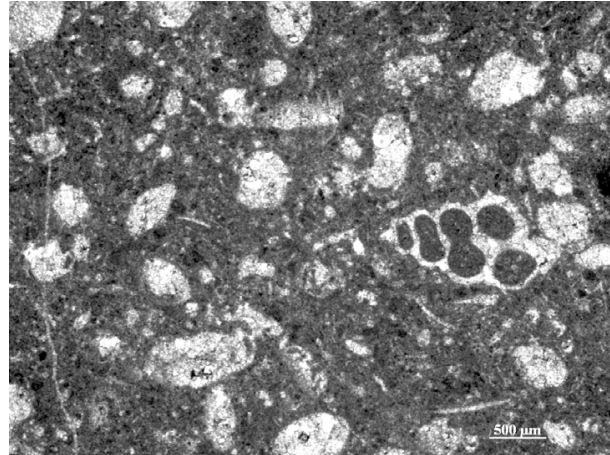

b

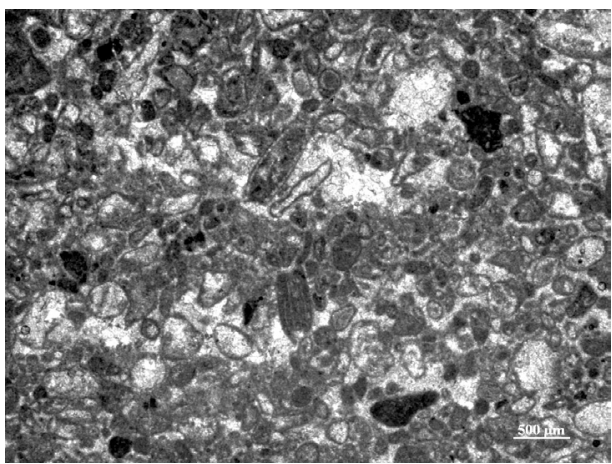

d

Fig. 13

Microfacies of the Dachstein Limestone at Kesztölc Quarry, Öreg Cliff and Fehér Cliff. a. intraclasticbioclastic grainstone (Ö-18); b. bioclastic wackestone with foraminifera and a gastropod (F-3); c. ostracodal micrite with a clast of the host rock (Ke-I, 3b sample); d. Peloidal bioclastic grainstone with Favreina pellet in the center (Ke-I, 1a sample); e. Aulotortus friedli (Kristan-Tollmann) (Ö-18) 
limestone (probably Lower Jurassic Hierlatz Limestone), was encountered in bedded Dachstein Limestone. On the western side of the valley, the sampled facies $C$ is typified by bioclastic, peloidal wackestone texture. In sample Vk-2, along with molds of foraminifera, ostracodes and bivalves, as well as fragments of Griphoporella sp. were encountered.

On the southwestern slope of Fehér Cliff facies $A$ and $C$ of the Dachstein Limestone were recognized. The facies $\mathrm{C}(\mathrm{F}-1,-2,-3)$ is characterized by peloidal, bioclastic wackestone and packstone texture with molds and partially recrystallized foraminifera, gastropods and fragments of bivalves (Fig. 13b). Typical laminar calcrete was recognized in F-4 with fenestral pores and larger solutionenlarged shrinkage pores. Geopetal fill is common in the pores, with ostracodebearing carbonate mud and silt in the basal part and coarse mosaic spar in the upper part of the cavities.

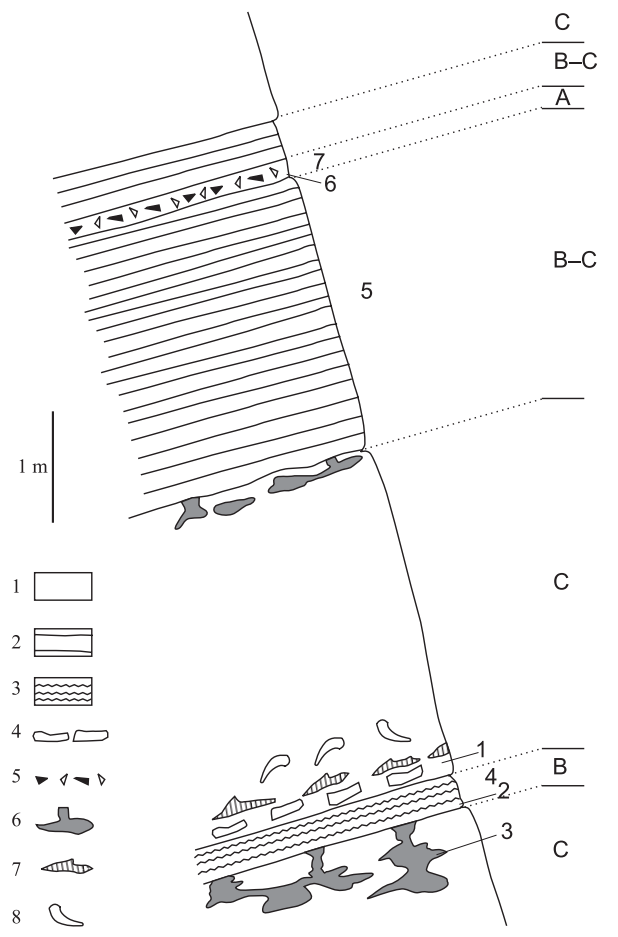

Fig. 14

Measured section (Ke-I) of Dachstein Limestone in Kesztölc Quarry (1-7: sampled layers). 1. subtidal facies; 2 . platy laminated structure; 3. stromatolite; 4 . rip-up clasts; 5 . black and lightcolored breccia; 6 . cavity filled with green mudstone; 7. solution cavities filled with coarse sparite; 8 . Megalodon fragments
The Dachstein Limestone is strongly tectonized in the large, still active Kesztölc Quarry. An exposure (Ke-I in Fig. 11), suitable for detailed study, was found in the southeastern part of the quarry (Fig. 14). Well-developed karstic cavity network in a facies $C$ bed was observed in the lowermost part of the measured section. The cavities are filled with pale green mudstone containing only tiny bioclasts and fragments of the host rock (Fig. 13c). The erosion surface is covered by green argillaceous limestone with $10-20 \mathrm{~cm}$ sized rip-ups of stromatolite, and then a stromatolite layer typified by microbial boundstone with small desiccation pores and larger solution pores. The basal layers are overlain by a 3 m-thick bed with fragments of megalodontids (member C). It is characterized by peloidal, bioclastic packstone-grain-stone texture (Fig. 13d); the bioclasts are generally micritized. Above an uneven karstified disconformity surface the next cycle begins with a $2.5 \mathrm{~m}$-thick laminated limestone bed (member B), from which two samples were taken. In one of the samples peloidal microsparite with 
Fig. 15

Uneven disconformity surface overlain by stromatolite at the base of a Lofer cycle. Kesztölc Quarry (Ke-II section)

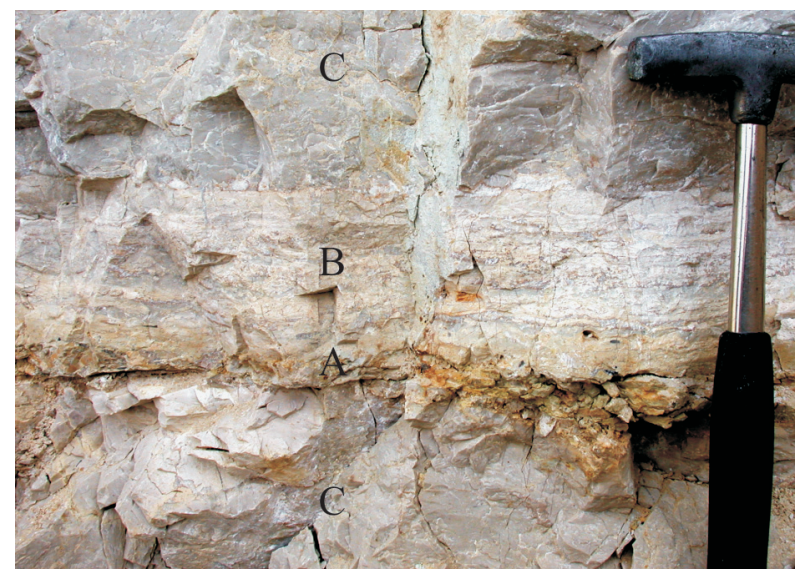

tiny shrinkage pores and sheet-cracks were found; the other is typified by clotted peloidal texture, locally with tubular microbial structures. The bed is truncated and covered by green marl with mm-sized mudstone clasts that is covered by platy limestone with sheet cracks, with $\mathrm{cm}$-sized solution cavities subparallel to the bedding. Samples Ke-II/2 and Ke-II/3 (collected from another part of the quarry, Fig. 15) contain numerous involutinids, although these are very crystallized in Ke-II/2; above it some individual Frondicularia woodwardi Howchin and nodosarid fragments occur. Involutina sinuosa, I. tumida and Aulotortus friedli suggest Late Norian age (Gazdzicki 1983; Senowbari-Daryan et al. 2010).

\section{Nagy-Strázsa Hill (Nagy-Strázsa-hegy)}

Nagy-Strázsa Hill is located south of Esztergom (Fig. 3). It is a small horst that is made up of Triassic carbonates and overlaying Eocene formations. The horst is surrounded by Oligocene deposits. Nagy-Strázsa Hill represents the southeastern part of the horst, where Sátorkó Cave and, above it, a cliff and a small abandoned quarry expose the Triassic rocks.

Inside the cave (near the entrance) spectacular bivalve coquina beds were encountered. Cm-sized fragments of megalodontids were observed in a definite horizon within the thin-shelled bivalves (Fig. 16). In the samples taken from these beds in between the coquinas, bioclastic-intraclastic grainstone was also observed. The coquinas consist mostly of $\mathrm{mm}$ - to $\mathrm{cm}$-sized fragments of bivalves (Fig. 17a). The shell fragments are commonly coated with micrite or a microbial coating, or locally with encrusting foraminifera. Gastropods and fragments of echinoderms are also present. The space among the shells is usually filled with sparite, or locally, in some samples, also with micrite. In a sample, fragments of thick-shelled bivalves, calcareous algae, and small gastropods occur in bioclastic grainstone. Bioclastic-intraclastic grainstone was also encountered. In these samples, along with abraded bioclasts of fine sand to fine pebble size, there occur 


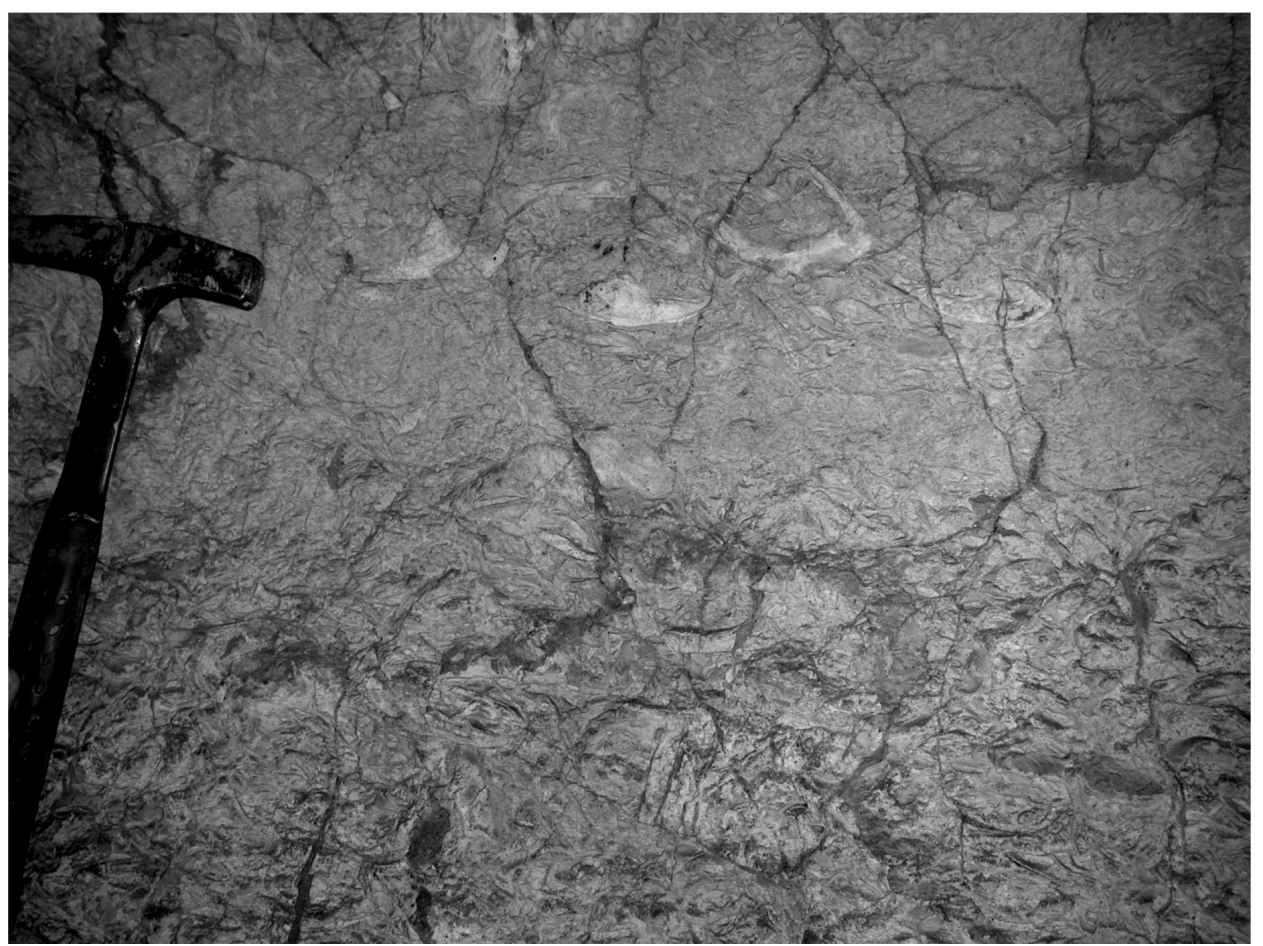

Fig. 16

Megalodont shells (in the upper part) and "Feketehegy-type" bivalve-coquina (in the lower part) on the wall of Sátorkő Cave

intraclasts and peloidal lithoclasts. Fragments of calcimicrobes, microbial nodules and microbial crusts are also found.

The coquina beds with the bioclastic-intraclastic grainstone intercalations may correspond to the storm coquinas of the Feketehegy Formation. The higher part of the low-angle platform foreslope may have been the deposition site of these beds.

The cliff above the entrance of the cave is typified by rudstone texture (Fig. $17 \mathrm{~b})$. The samples taken from here contain fragments of calcimicrobes, calcareous sponges, calcareous algae (Fig. 17c-d), thick-shelled bivalves and some echinoderm detritus and foraminifera. Lithoclasts were also found in some samples. The intergranular pores are partly filled with sparite partly with micrite. On the basis of the macroscopic and microscopic features of these rocks they can be interpreted as talus breccia; they may have formed at the base of the relatively steep slope of a mound consisting mostly of microbial builders and encrusters. 



Fig. 17

Microfacies of the Dachstein Limestone at Strázsa Hill. a. Bivalve coquina (S-1 sample); b. Lithoclastic rudstone with isopach sparite intergranular cavity-fill (S-6 sample); c. Diplopora adnetensis Flügel (S-14 sample) Norian; d. Diplopora decastroi Di Stefano et Senowbari-Daryan (S-13 sample)

\section{Sections of basinal carbonates}

Outcrops of the Upper Triassic basinal facies occur on the northeastern side of the Pilis Mts (Fig. 3), in the neighborhood of Pilisszentlélek. The exposures of the Feketehegy Limestone in Cserepes Valley (along the Szentlélek stream) was already described by Schafarzik (1884a) and much later by Nagy (1968). The type section of the formation exposed on the slope of Fekete-hegy was studied in detail by Oravecz $(1961,1987)$, Kovács and Nagy (1989) and recently Haas et al. (2005). Within the framework of a recently carried-out project, outcrops at the cliffs of Háromszáz-garádics (northwestern slope of Fekete Hill) and exposures along Cserepes Valley (Fig. 18) were investigated.

Fekete Hill (Fekete-hegy)

The stratotype section of the Feketehegy Formation (Fh in Fig. 18) was studied by Haas et al. (2005) in detail. They defined the following main facies types: thickbedded oolitic grainstone; thick bedded rudstone with reef-derived bioclasts and 

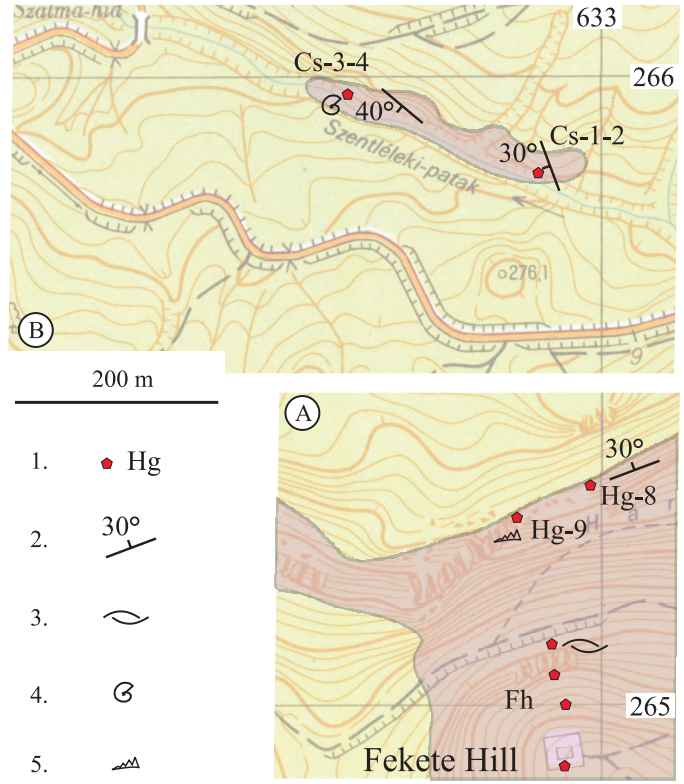

Fig. 18

Surface extent (lilac on the map) and sampling sites of the Feketehegy Formation on the northwestern slope of Fekete Hill (A) and along Cserepes Valley (B). 1. sampling site, 2. dip; 3. bivalve coquina; 4. ammonite data; 5 . conodont data. Abbreviation: Cs - Cserepes Valley; Fh - Fekete Hill; Hg - Háromszáz-garádics

Fig. $19 \downarrow$

The cliffs of Háromszáz-garádics are built up by well-bedded Feketehegy Limestone

lithoclasts; thick cross-bedded and parallel-bedded bivalve (Pteria and Pseudomyoconcha) coquina and calcarenite; laminated limestone with grainstone-wackestone-mudstone laminae.

The huge cliffs of Háromszázgarádics ( $\mathrm{Hg}$ in Fig. 18) were sampled for conodonts by Kovács and Nagy (1989) (their use of the name Fehér-kő for the site was improper, since Fehér-kô is located to the NW of Fekete Hill). Based on the conodont assemblage (Metapolygnathus slovakensis) the succession was assigned to the Middle-Upper Norian (Kovács and Nagy 1989).

The sequence at Háromszázgarádics (Fig. 19) is made up by the alternation of well-bedded to laminated bituminous limestone (dolomitic in the lowermost part)

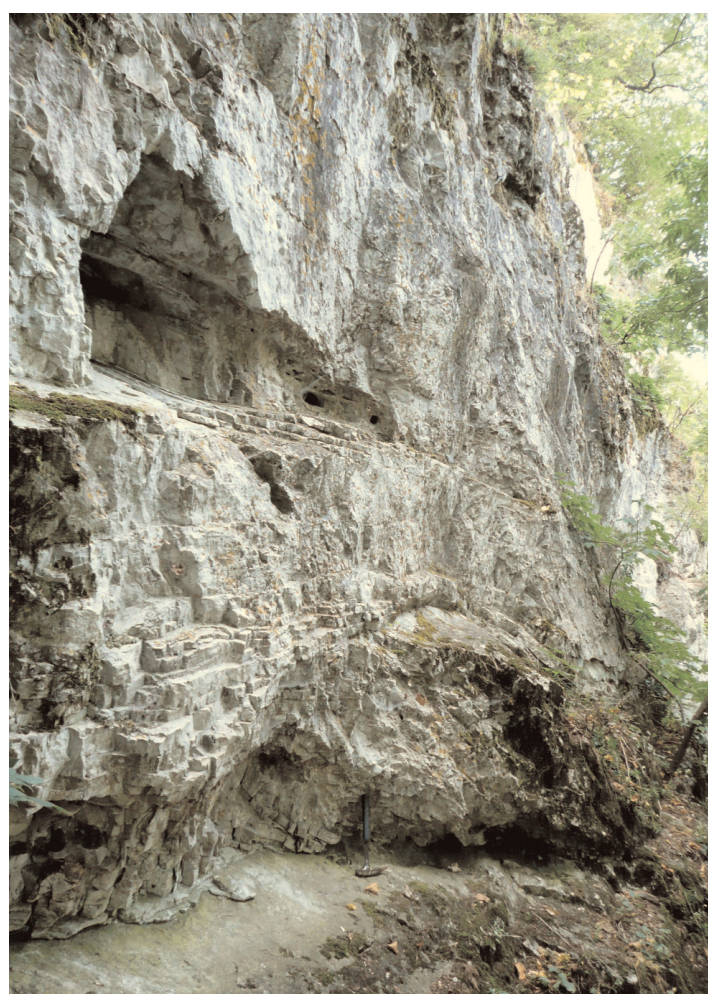


and thick bedded limestone. Slump structures are common. The laminated beds are made up of $0.5-0.8 \mathrm{~cm}$-thick laminae, which are commonly graded. Calcarenite (grainstone-packstone) with fecal pellets and peloids, fragments of mollusks, ostracodes and foraminifera (Glomospira sp., Trochammina sp.) occur at the base of the laminae that are commonly bioturbated. It progresses upward into mudstone or bioclastic wackestone, rich in thin-shelled ostracodes and sponge spicules (calcite molds). This lithofacies can be interpreted as a distal tempestite. The thick beds are typified by microsparitic mudstone or peloidal wackestone texture with small amounts of thin-shelled ostracodes, globochaete and sponge spicules. They are interpreted as autochthonous basin facies.

\section{Cserepes Valley (Cserepes-völgy)}

The other classical section of the Feketehegy Limestone occurs in Cserepes Valley, 200-400 m ESE of Szalma-híd (Szalma Bridge) (Cs-3-4 in Fig. 18). Oravecz (1961) collected Rhabdoceras suessi from this section. The conodont Misikella hersteini was encountered by Krystyn (pers. com.) suggesting latest Norian Early Rhaetian age (Krystyn et al. 2009).

Along the valley platy, laminated bituminous limestone is exposed, locally with bivalve-coquina interbeds. The platy limestone layers are characterized by bioclastic, peloidal wackestone texture with fecal pellets, thin-shelled ostracodes, and bivalves, sponge spicules, ammonite embryos and foraminifera. The foraminiferal fauna mainly consists of uniquely well-preserved Oberhauserellidae $\mathrm{sp}$. (the hyaline wall structure and pores can be studied), and a few Ophtalmidium cf. triadicum (Kristan) (Fig. 20e, f). Based on the sedimentological features and fossil content it can be interpreted as a basinal facies.

This succession is punctuated by uneven erosion surfaces that are usually overlain by bivalve coquina horizons containing fragments of dasycladalean algae (Diplopora decastroi Di Stefano et Senowbari-Daryan, Clypeina besici Pantic, Heteroporella zankli Ott), and microbial nodules (Fig. 20b-d). These are tempestite horizons.

\section{Sedimentary model}

Based on the facies investigation of the Upper Triassic formations of the Pilis Range the following sedimentary environments could be interpreted.

The Lofer-cyclic succession of Pilis Hill and Kétágú Hill was formed in an internal platform (lagoon) environment (Haas 2004). Based on the dasycladalean

flora (Heteroporella zankli Ott, Physoporella leptotheca Kochansky-Devidé, Griphoporella curvata (Gümbel) Pia, Gyroporella vesiculifera Gümbel) found by us and the previously published megalodont assemblage (Végh-Neubrandt 1982) the cyclic peritidal-lagoon facies was deposited during the Norian.

Various facies types of the Feketehegy Limestone could be recognized WNW of Pilis Hill, on the northeastern side of the Pilis Range. In several outcrops and in 

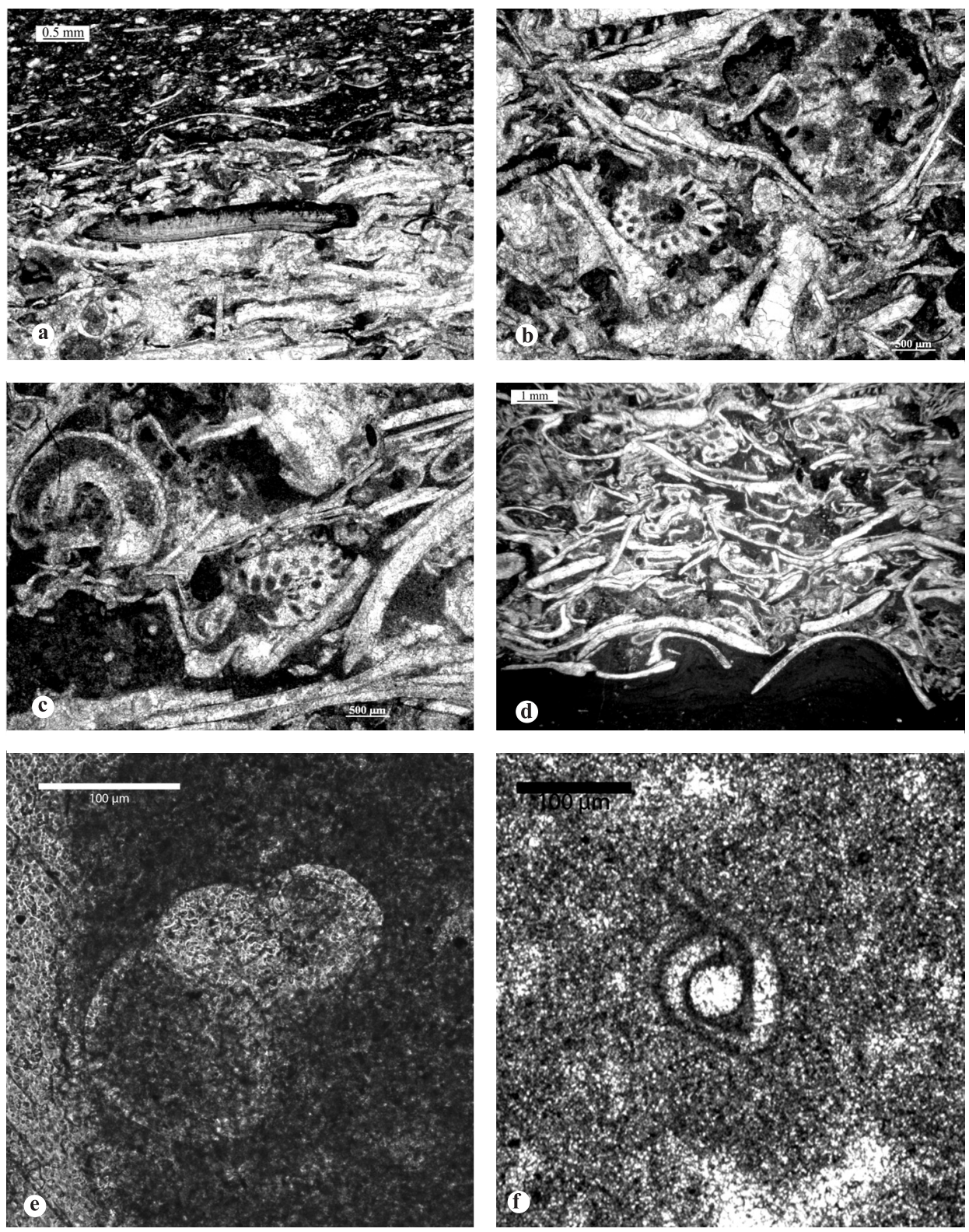

Fig. 20

Microfacies of the Feketehegy Limestone in Cserepes Valley. a. Graded bivalve coquina (Cs-2, 10 sample); b. Bivalve coquina with Diplopora decastroi Di Stefano et Senowbari-Daryan algae (Cs-2, 3. sample); c. Diplopora decastroi Di Stefano et Senowbari-Daryan in platform-derived calcarenite (Cs-2, 7 sample); d. Mudstone overlain by graded bivalve coquina (Cs-2, 2 sample); e. Oberhauserellidae sp. (Cs-1); f. Ophtalmidium cf. triadicum (Kristan) (Cs-3) 


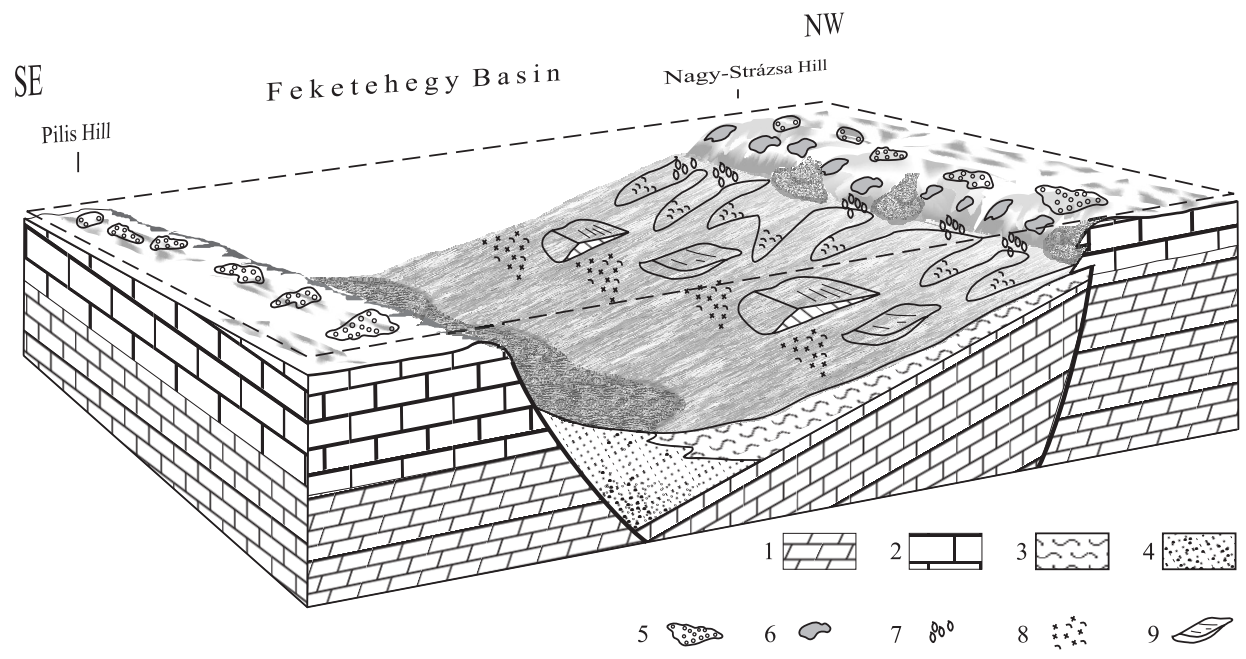

Fig. 21

Late Norian - Early Rhaetian sedimentary model of the intraplatform Feketehegy Basin. 1. Hauptdolomit; 2. Dachstein Limestone; 3. Feketehegy Limestone; 4. talus breccia; 5. ooid-shoals; 6. patch-reefs; 7 . bivalves; 8 . bioclastic calcarenite; 9 . storm ridges

the type-section along the forest road on the northeastern slope of Fekete Hill, bivalve storm coquinas, and in some beds redeposited ooids, reef-derived bioclasts and lithoclasts were encountered, suggesting storm-induced deposition above the storm wave-base and near the habitats of the shallow-marine bivalves and patch reefs (Haas et al. 2005). In the outcrops at Háromszáz-garádics and Cserepes Valley, fine-grained distal tempestites, deposited in a restricted, oxygendepleted basin bellow the storm wave-base, were found. These observations imply a very low-angle slope (ramp) forming the gently-dipping side of the asymmetric Feketehegy Basin (Haas 2002; Haas et al. 2005).

At Nagy-Strázsa Hill the storm coquinas are directly overlain by reef talus breccia, implying progradation of the patch reefs onto the storm-dominated inner ramp, i.e. the boundary belt between the platform and the very low-angle slope.

According to our facies interpretation and the available age data, the Feketehegy Basin, controlled by extensional tectonics, was formed within the Dachstein Platform during the middle part of the Norian (Fig. 21). Contemporaneous extensional basins are known from several locations of the Southern Alps: in Lombardy (Jadoul et al. 1992; Gaetani et al. 1998), in the Carnian Pre-Alps (Carulli et al. 1998; Cozzi and Hardie 2003), and also in the Northern Calcareous Alps (Piller and Lobitzer 1979; Piller 1981; Stanton and Flügel 1989, 1995).

In the area where the shallow platform conditions were preserved (NagyStrázsa Hill and probably also the area of Pilis Hill located on the opposite high) 
patch reefs and ooid-oncoid shoals were developed along the platform margin. The cyclic carbonate sedimentation in the internal platform lagoon was controlled by high-frequency sea-level fluctuations. The appearance of Tethyan ammonoids (Rhabdoceras, Cserepes Valley) in the latest Norian suggests sealevel rise caused decreasing restriction of the intraplatform basin.

Platform progradation onto the gentle slope (Nagy-Strázsa Hill) may have commenced during the latest Norian to earliest Rhaetian highstand period. Contemporaneous platform progradation was reported by Krystyn et al. (2009) in the Dachstein area.

At this time we have no relevant biostratigraphic data for the Rhaetian stage in the Pilis Range, even though Nagy $(1968,1969)$ assigned the upper part of the Dachstein Limestone to the Rhaetian. It is therefore not clear whether evolution of the Feketehegy Basin had really ended due to progradation of the Dachstein Platform by the earliest Rhaetian, or whether the basin survived during the Rhaetian (or even into the Liassic), as was the case of the Csővár Basin.

\section{Conclusions}

Based on studies of Upper Triassic formations exposed in the Pilis Range, three types of roughly coeval successions could be distinguished.

a) At the southeastern foot of Pilis Hill cyclic dolomite is exposed that can be classified as Hauptdolomit. Over a thin transitional interval it is overlain by Lofer-cyclic Dachstein Limestone, and this characteristic lithofacies makes up Pilis Hill and the southwestern side of Fekete and Kétágú Hills. These sequences represent an inner platform environment that was subject to periodical sea-level oscillation. The exposed uppermost part of the Hauptdolomit is probably of Middle Norian and the overlying Dachstein Limestone of Middle to Late Norian age.

b) On the northwestern side of Fekete Hill and Kétágú Hill, and also further NE in Cserepes Valley, storm-dominated low-angle slope and basin facies of the Feketehegy Formation are known. Dark gray, platy-laminated dolomite beds, probably of Middle Norian age, occur at the basal part of the succession. Based on conodont and ammonite content the overlying limestone sequence can be assigned to a range between the late Middle Norian to latest Norian-earliest Rhaetian.

c) At Nagy-Strázsa Hill, in the northern part of the Pilis Range, bivalve coquinas that can be assigned to the Feketehegy Formation are overlain by reef-derived bioclastic beds. This section can be interpreted as the progradation of a platform margin onto a low-angle slope, although the exact age of this event could not be determined.

The observations presented above imply the following evolutionary history:

Within the large Dachstein Platform, extensional tectonics may have resulted in the development of an intraplatform basin during the middle part of the 
Norian. The initial stage of this process is indicated by the appearance of platylaminated dolomite above platform carbonates. Thereafter an asymmetric basin was formed. It may have been bounded by a steep slope on one side and a gentle one on the opposite side; it was closed westward and connected with deeper basins eastward. The Feketehegy Formation was deposited on the ramp-like gentle slope. Platform progradation commenced on this margin of the basin, probably in the latest Norian - earliest Rhaetian. However, we do not know whether this process led to the termination of the entire basin, or whether basinal conditions continued during the latest Triassic or even into the earliest Jurassic, as in the case of the Hármashatárhegy Basin in the Buda Mts or of the Csővár Basin in the blocks east of the Danube.

\section{Acknowledgements}

Investigations of the Upper Triassic formations of the Pilis Range were supported by the Hungarian Research Fund (OTKA K-68224, T. Budai and OTKA K-81296, J. Haas). The authors express their gratitude to the Ariadne Speleologist Group for carrying out sampling along the corridors of the Ajándék, Legény and Leány Caves. Valuable reviewers' comments and corrections by Gerhard Mandl and Pál Pelikán are gratefully acknowledged.

\section{References}

Balogh, K. 1961: A Buda-Pilisi-hegység triász képződményeinek problematikája (Problems of the Triassic formations of the Buda-Pilis Mts). - Manuscript. Magyar Állami Földtani, Geofizikai és Bányászati Adattár, T.939, 83 p. (In Hungarian.)

Balogh, K. 1981: Correlation of the Hungarian Triassic. - Acta Geologica Hungarica, 24, pp. 3-48.

Budai, T., L. Gyalog (szerk.) 2009: Magyarország földtani atlasza országjáróknak, 1:200 000 (Geological Map of Hungary for Tourists). - Geological Institute of Hungary, 248 p.

Budai, T, S. Kovács 1986: A rezi dolomit rétegtani helyzete a Keszthelyi-hegységben (Contributions to the stratigraphy of the Rezi Dolomite Formation (Metapolygnathus slovakensis, Conodonta, Upper Triassic) from the Keszthely Mts [W Hungary]). - Annual Report of the Hungarian Geological Institute, 1984, pp. 175-191. (In Hungarian with English abstract.)

Caruli, G.B., A. Cozzi, G. Longo Salvador, M. Ponton, F. Podda 1998: Evidence od synsedimentary tectonic activity during the Norian-Lias (Carnian Prealps, Northern Itraly). - Mem. Soc. Geol. It., 53, pp. 403-415.

Cozzi, A., L. A. Hardie 2003: Third-order depositional sequences controlled by synsedimentary extensional tectonics" evidence rom Upper Triassic carbonates of the Carnian Prealps (NE Italy). - Terra Nova, 15/1, pp. 40-45.

Ferencz, K. 1953: A Pilishegy és a tőle D-re eső terület földtani viszonyai (Conditions géologiques du Mont Pilis et du territoire situé au S de celui-ci). - Annual Report of the Hungarian Geological Institute, 1943/III., pp. 7-29. (In Hungarian with French abstract.)

Gaetani, M., M. Gnaccolini, F. Jadoul, E. Garzanti 1998: Multiorder sequence stratigraphy in the Triassic system of the western Southern Alps. - In: Mesozoic-Cenozoic Sequence Stratigraphy of European Basins, SEPM Special Publication 60, pp. 701-717.

Gazdzicki, A. 1983: Foraminifers and biostratigraphy of Upper Triassic and Lower Jurassic of the Slovakian and Polish Carpathians. - Palaeont. Polonica, 44, pp. 285-298. 
Haas, J. 2002: Origin and evolution of Late Triassic backplatform and intraplatform basins in the Transdanubian Range, Hungary. - Geologica Carpathica, 53/3, pp. 159-178.

Haas, J. 2004: Characteristics of peritidal facies and evidences for subaerial exposures in Dachsteintype cyclic platform carbonates in the Transdanubian Range, Hungary. - Facies, 50, pp. 263-286.

Haas, J., T. Budai 1999: Triassic sequence stratigraphy of the Transdanubian Range, Hungary. Geologica Carpathica, 50/6, pp. 459-475.

Haas, J., E. Tardi-Filácz, A. Oravecz-Scheffer, F. Góczán, L. Dosztály 1997: Stratigraphy and sedimentology of an Upper Triassic toe-of-slope and basin succession at Csővár, North Hungary. - Acta Geologica Hungarica, 40/2, pp. 111-177.

Haas, J., T. Budai, K. Hips, Gy. Konrád, Á. Török 2002: Magyarországi triász fáciesterületek szekvencia-rétegtani elemzése (Sequence stratigraphy of Triassic facies areas in Hungary). Bulletin of the Hungarian Geological Society, 132/1, pp. 17-43. (In Hungarian with English abstract.)

Haas, J., T. Budai, I. Szente, O. Piros, E. Tardiné Filácz 2005: Felső-triász lejtô- és medencefáciesú rétegsorok a Pilisben és a Tatabányai medencében (Upper Triassic slope and basin sequences in the Pilis Mts and the Tatabánya Basin). - Bulletin of the Hungarian Geological Society, 135/4, pp. 513-543. (In Hungarian with English abstract.)

Jadoul, F., F. Berra, S. Frisia 1992: Stratigraphyic and paleogeographic evolution of a carbonate platform in an extensional tectonic regime: the example of the Dolomia Principale in Lombardy (Italy). - Rivista Italiana Paleontologia Stratigrafia, 98/1, pp. 29-44.

Jadoul, F, M.T. Galli, F. Berra, S. Cirilli, P. Ronchi, A. Paganoni 2004: The Late Triassic-Early Jurassic of the Lombardy Basin: stratigraphy, palaeogeography and palaeontology. - 32nd International Geological Congress, Florence, Italy, Field Trip Guide Books 6, P68, 36 p.

Koch, A. 1871a: A Szt.-Endre-Vissegrádi és a Pilis hegység földtani leírása (Geological description of the Szt-Endre-Visegrád Mts and the Pilis Mts). - Magyar Királyi Földtani Intézet Évkönyve, 1/2, pp. 141-198. (In Hungarian.)

Koch, A. 1871b: Geologische Beschreibung des Sct. Andra-Vissegráder und des Piliser Gebirges. Jahrbuch der Kön. Ung. Geologischen Anstalt, I/4, pp. 237-291.

Kovács, S., G. Nagy 1989: A Pilis hegység aviculás és halobiás mészkőösszletének kora (Contributions to the age of the Avicula- and Halobia-limestones (Fekete-hegy Limestone Formation) in the Pilis Mts (NE Transdanubian Central Range, Hungary). - Annual Report of the Hungarian Geological Institute, 1987, pp. 95-129. (In Hungarian with English abstract.)

Krystyn, L., G.W. Mandl, M. Schauer 2009: Growth and termination of the Upper Triassic platform margin of the Dachstein area (Northern Calcareous Alps, Austria). - Austrian Journal of Earth Sciences, 102, pp. 23-33.

Lóczy, L. 1913: A Balaton környékének geológiai képződményei és ezeknek vidékek szerinti telepedése (Geological formation of the environ of Lake Balaton and their regional extension). - A Balaton tudományos tanulmányozásának eredményei (Results of researches of Lake Balaton), 1/1, 617 p. (In Hungarian.)

Lóczy, L. 1916: Die geologischen Formationen der Balatongegend und ihre regionale Tektonik. Resultate der wissenschaftlichen Erforschung des Balatonsees, 1/1, 716 p. Wien.

Nagy, G. 1964a: A Dorogi-medence keleti peremének hegységszerkezeti kérdései (Tektonische Probleme des östlichen Randes des Doroger Beckens). - Annual Report of the Hungarian Geological Institute, 1961, pp. 315-322. (In Hungarian with German abstract.)

Nagy, G. 1964b: A Dorogi-medence keleti peremének földtani felépítése (Geology of the eastern border of the Dorog Basin). - Annual Report of the Hungarian Geological Institute, 1962, pp. 183-194. (In Hungarian with English abstract.)

Nagy, G. 1968: Magyarázó a Dorogi-medence földtani térképéhez, 10 000-es sorozat, Pilisszentlélek (Explanatory book to the geological map series of the Dorog Basin, 1:10 000, Pilisszentlélek). Geological Institute of Hungary, 42 p. (In Hungarian.) 
Nagy, G. 1969: Magyarázó a Dorogi-medence földtani térképéhez, 10 000-es sorozat, Kesztölc (Explanatory book to the geological map series of the Dorog Basin, 1:10 000, Kesztölc). Hungarian Geological Institute, 50 p. (In Hungarian.)

Oravecz, J. 1961: A Gerecse és a Buda-Pilisi-hegység közötti rögterület triász képződményei (Die Triasbildungen des Schollengebietes zwischen den Gerecse und Buda-Piliser Gebirgen). Bulletin of the Hungarian Geological Society, 91/2, pp. 173-185. (In Hungarian with German abstract.)

Oravecz, J. 1987: Pilis, Pilisszentlélek, Fekete-hegy. - Geological key sections of Hungary. Geological Institute of Hungary.

Oraveczné-Scheffer, A. 1987: A Dunántúli-középhegység triász képződményeinek foraminiferái (Triassic foraminifers of the Transdanubian Central Range). - Geologica Hungarica series Palaeontologica, 50, $331 \mathrm{p}$.

Piller, W., H. Lobitzer 1979: Die obertriassische karbonatplattform zwischen Steinplatte (Tirol) und Hochkönig (Salzburg). - Verhandlungen der Geologischen Bundesanstalt, 1979/2, pp. 171-180.

Piller, W. 1981: Steinplatte (Tirol). - In: Flügel, E. (Ed.): International Symposium on Triassic Reefs, Erlangen. Guide Book, pp. 171-184.

Reményi, K. 1950: Jelentés a Pilis hegység ÉNy-i részében végzett földtani megfigyelésekről (Report on geological observations in the north-western part of the Pilis Mts). - Manuscript. Magyar Földtani, Geofizikai és Bányászati Adattár, T.164, 10 p. (In Hungarian.)

Rettori, R. 1995: Foraminiferi del Trias inferiore e medio della Tetide: Revisione tassonomica, stratigrafia ed interpretazione filogenetica. - Universite de Geneve, Département de Géologie et de Paléontologie 18, 147 p.

Schafarzik, F. 1884a: Jelentés az 1883. év nyarán a Pilis hegységben eszközölt földtani részletes felvételrôl. - Földtani Intézet Évi Jelentése, 1883, pp. 91-114.

Schafarzik, F. 1884b: Geologische Aufnahme des Pilis-Gebirges und der beiden "Wachtberge" bei Gran. - Jahresbericht der König. Ung. Geologischen Anstalt, 1883, pp. 105-132.

Schafarzik, F. 1898: Budapest és Szt.-Endre vidéke, 1:75 000 (Environ of Budapest and Szt-Endre, 1:75 000). - Geologische Aufnahme der könig. ung. Geologischen Anstalt. (In Hungarian.)

Schafarzik, F. 1902: Budapest és Szt.-Endre vidéke. - Magyarázatok a Magyar Korona Országainak résztletes földtani térképéhez, 15. zóna/XX. rovat, 1:75 000 (Explanations to the detailed geological map of the counties of the Hungarian Crown, zone 15, column XX, 1:75 000). Magyar Királyi Földtani Intézet, 61 p. (In Hungarian.)

Schafarzik, F. 1904: Die Umgebung von Budapest und Szt. Endre. Erlanterungen zur Geologischen Spezialkarte der Lander der Ungarische Krone, Blatt Zone 15, Kol. XX, 1:75 000. Königl. Ung. Geologischen Anstalt, $70 \mathrm{p}$.

Schafarzik, F., A. Vendl 1929: Geológiai kirándulások Budapest környékén (Geological excursions in the vicinity of Budapest). - Geological Institute of Hungary, 341 p. (In Hungarian.)

Senowbari-Daryan, B., K. Rashidi, H. Torabi 2010: Foraminifera and their associations of a possibly Rhaetian section of the Nayband Formation in central Iran, northeast of Esfahan. - Facies, 56, pp. 567-596.

Stache, G. 1866: Die geologischen Verhaltnisse der Umgebung von Waitzen in Ungarn. - Jahrbuch der Geologischen Reichsanstalt, 16/3, pp. 277-328. Wien.

Stanton, R.J., E. Flügel 1989: Problems with reef models: the Late Triassic Steinplatte "reef" (Northern Alps, Salzburg/Tyrol, Austria). - Facies, 20, pp. 1-138.

Stanton, R.J., E. Flügel 1995: An accretionary distally steepened ramp at an intrashelf basin margin: an alternative explanation for the Upper Triassic Steinplatte "reef" (Northern Calcareous Alps, Austria). - Sedimentary Geology, 95, pp. 269-286.

Végh, S-né 1978: Calcarie de Fekete-hegy. - In: Lexique Stratigr. Intern., 1.9. Hongrie, Paris, pp. 205-206.

Végh-Neubrandt, E. 1982: Triassische Megalodontaceae. - Akadémiai Kiadó, Budapest, 526 p.

Vígh, Gy. 1928: Adatok a budai és a gerecsehegységi triász ismeretéhez (Zur Kenntnis der Trias im Budaer (Ofner) und Gerecse Gebirge). - Földtani Közlöny 57, pp. 53-63, (pp. 139-144). 